\title{
Uzavření muzeí jako výzva k dalšímu vzdělávání průvodců v Muzeu Brněnska
}

Monika Mikulášková

1 Project Zero: Visible Thinking. Dostupné z: http:// www.pz.harvard.edu/projects/ visible-thinking.

2 TISHMAN, Shari a Patricia PALMER. Works Of Art Are Good Things To Think About. In: Evaluating the Impact of Arts and Cultural Education,

conference proceedings, Centre Pompidou, 2007, Paris, 89-101.

Mgr. Monika Mikulášková Muzeum Brněnska m.mikulaskova@mbrn.cz

\section{Closure of Museums as a Call for Further Education of Guides in the Museum of the Brno Region}

V roce 2020 se muzea, stejně jako celá společnost, musela vyrovnávat s komplikovanou situací spojenou s pandemií nového typu koronaviru. Průvodci ve dvou obdobích uzavření muzeí často přecházeli na jiné typy pracovní náplně, pomáhali například kurátorům a dokumentátorům při práci se sbírkami či se podíleli na tvorbě obsahu na sociální sítě nebo webové stránky institucí. V Muzeu Brněnska měli průvodci možnost využít toto nestandardní období také k dalšímu vzdělávání. Muzeum Brněnska vzniklo jako Okresní muzeum Brno-venkov v 60. letech 20. století. V současnosti sestává $\mathrm{z}$ celkem šesti poboček, pět z nich se nachází v okolí města Brna a jedna přímo $v$ jeho centru. Zaměřením se jedná o tři vlastivědná muzea (Muzeum ve Šlapanicích, Muzeum v Ivančicích, Podhorácké muzeum), dva specializované památníky (Památník písemnictví na Moravě a Památník Mohyla míru). Šestou, nejnovější, pobočkou instituce je Vila Löw-Beer v Brně, která sídlí $\mathrm{v}$ památkově chráněné budově a etabluje se jako muzeum architektury. Se zpřístupňováním dalších kulturních památek jsou spojeny dvě jmenované pobočky Muzea Brněnska: Památník písemnictví na Moravě sídlí v prostorách benediktinského kláštera v Rajhradě a Podhorácké muzeum v areálu cisterciáckého kláštera Porta coeli.

\section{Připravná fáze projektu a inspirační zdroje}

Průvodcům byla nabídnuta možnost účastnit se tzv. "minikurzů", které směřovaly $\mathrm{k}$ obohacení jejich metodické základny. Nově získané poznatky mohli následně využít nejen v edukačních programech, ale i při běžné komentované prohlídce. Potřeba podobného vzdělávání souvisí s organizační strukturou instituce:
Průvodci v Muzeu Brněnska zajištují každodenně komentované prohlídky památkových objektů na čtyřech z šesti poboček a na všech šesti pobočkách se průvodci ve spolupráci s muzejní pedagožkou podílejí na přípravě a realizaci edukačních aktivit pro školy i veřejnost. Aktuálně pracuje v celé organizaci patnáct průvodců a jedna muzejní pedagožka.

Základní požadavky na výběr metod, jež budou zařazeny do programu kurzu, vycházely z běžného provozu instituce: Bylo třeba vybrat takové, které lze zařadit do standardní komentované prohlídky, nevyžadují použití specifických pomůcek a zásadně nenavýší čas prohlídky. Metody musely být využitelné bez ohledu na věkovou skupinu a typ exponátu. Na základě těchto požadavků jsme proto zvolili metody, které byly vyvinuty a publikovány $\mathrm{v}$ rámci výzkumů Project Zero vědci z Harvard Graduate School of Education. Tyto metody patří k oblíbeným a široce využívaným zejména v galerijním prostředí. Konkrétně byly metody čerpány z projektů Visible Thinking a Artful Thinking.

Projekt Visible Thinking navázal na výzkum švédských akademiků z Lemshaga Akademi a zaměřuje se na rozvoj vědeckého rámce a praktických rutin, jež směřují k integrování rozvoje uvažování a myšlení do edukačního obsahu. Cílem výzkumu bylo zjistit, jak se kultivují dispozice k myšlení, jak samotné myšlení probíhá a jak tyto procesy podpořit ${ }^{1}$. Druhý z projektů, které byly využity při formování minikurzů, Artful Thinking, se věnoval obdobným cílům, avšak za pomoci využití uměleckých předmětů. Shari Tishman a Patricia Palmer, autorky projektu, uvádějí, že umělecká díla jsou velmi komplexní a mnohovrstevnatá, a právě proto jsou vhodná k poznávání komplikovaného a různorodého světa kolem nás ${ }^{2}$. Stejné 
charakteristiky lze jistě najít i u jiných typů předmětů z muzejních sbírek.

Oba projekty na teoretické rovině vychází $\mathrm{z}$ odmítnutí Bloomovy taxonomie a navržení šesti ${ }^{3}$ (jinde osmi) ${ }^{4}$ různých druhů kognitivních procesů, jež jsou vzájemně provázány a dochází $\mathrm{k}$ nim chaotičtěji (oproti hierarchicky organizovanému systému Blooma a jeho následovníků). Jedná se o: observing closely and describing what's there (důkladné pozorování a popisování viděného), building explanations and interpretations (vysvětlování a interpretování), reasoning with evidence (uvažování na základě důkazů), making connections (hledání souvislostí), considering different viewpoints and perspectives (zvažování různých úhlů pohledu a perspektiv), capturing the heart and forming conclusions (zachycování jádra obsahu a formování závěrů), wondering and asking questions (promýšlení a kladení otázek), uncovering complexity and going below the surface of things (odhalování spletitostí a zkoumání do hloubky) 5 .

Rozvoj jednotlivých procesů je pak podporován jednoduchými rutinami, metodami, které jsou prripravené pro okamžité použití nejen ve školních tř́dách. Výzkumníci vyjmenovávají řadu pozitiv těchto rutin, pro projekt prŕípravy minikurzu bylo významné především to, že jsou orientované na konkrétní specifické typy myšlení, sestávají pouze $\mathrm{z}$ několika krátkých kroků, lze se je jednoduše naučit, je poměrně snadné s jejich pomocí učit a mohou být užívány v různých kontextech ${ }^{6}$.

Při plánování konkrétní realizace jsme se pak inspirovali mimo jiné dvěma MOOC kurzy (massive open online course), které připravily National Gallery of Art ve Washingtonu a Museum of Modern Art $v$ New Yorku. Oba kurzy zprostředkovávaly praktické využití metod z výzkumů Project Zero pro učitele a muzejní pedagogy. Kurz washingtonské galerie Teaching Critical Thinking through $\mathrm{Art}^{7}$ na platformě $e d X^{8}$ predstavoval vybrané metody zejména $\mathrm{z}$ oblasti prvních tří vyjmenovaných kognitivních procesů především z projektu Artful Thinking (Shari Tishman se také podílela na prrípravě tohoto kurzu). Podstatně méně obsáhlý kurz MoMA
Art and Activity: Interactive Strategies for Engaging with Art $^{9}$ na platformě Coursera ${ }^{10}$ se zaměřoval na aktivizační metody, jak z výše jmenovaných projektů, tak (v menší míre) z dalších zdrojů. Oba kurzy nabízejí seznámení s metodami aktivní formou, často za pomocí př́́kladů z praxe muzejních institucí i škol.

Dříve, než byla připravena konkrétní verze minikurzu, realizovala všechny metody muzejní pedagožka během práce s organizovanými skupinami a dále prověřovala jejich výuku s malou skupinou vybraných kolegů na jedné z poboček (zastoupeny profese průvodce, kurátor a dokumentátor). Na tuto zkušební fázi navázalo zúžení výběru jednotlivých metod, př́íprava samotného obsahu prvního kurzu a jeho nabídnutí v rámci všech šesti poboček Muzea Brněnska. Na základě úspěchu prvního kurzu byla později připravena další setkání.

\section{Vybrané metody a konkrétní aspekty realizace}

Z širokého množství zpracovaných rutin, jak metody nazývají zmíněné projekty, bylo třeba zvolit ty, které budou nejvíce užitečné pro průvodce Muzea Brněnska. Pro první setkání byly zvoleny metody See/Think/Wonder (STW), What makes you say that (WMYST), Elaboration Game a Creative Questions.

Metoda STW patří k nejznámějším a nejvíce využívaným. Skládá ze tři částí: Nejprve prosíme účastníky, aby popsali, co vidí na daném exponátu, dále se jich ptáme, co si o něm myslí (podle typu exponátu můžeme směřovat např́ílad $\mathrm{k}$ tématu či funkci) a následně žádáme návštěvníky, aby pokládali otázky, které je napadají, ptali se na to, co by chtěli dále vědět, aby předmět lépe poznali ${ }^{11}$. Za fází Think často následuje základní výklad, což ve fázi Wonder umožňuje klást otázky, které základní informace rozšiřují nebo se ptají po obecných principech a tématech. WMYST je poměrně jednoduchá strategie, kdy účastníci nejprve popisují, co vidí, např. co se děje na obraze, a následně se snaží najít pozorovatelné důkazy, které
3 TISHMAN, Shari a Patricia PALMER. Artful Thinking: Stronger Thinking and leasing through the power of art. Final report submitted to Traverse Area of Public Schools. November, 2006, s 7-10. Dostupné online $z$ : http://www. pz.harvard.edu/resources/ final-report-artful-thinking. 4 RITCHHART, ROn, CHURCH, Mark a Karin MORISON. Making Thinking Visible: How to Promote Engagement, Understanding, and Independence for All Learners, 2011, s. 11

5 Tamtéž, s. 11-13. (Překlad autorky).

6 TISHMAN, Shari a Patricia PALMER. Artful Thinking..., S. 14.

7 Teaching Critical Thinking through Art. Dostupné z: https://www.edx.org/course/teaching-critical-thinking-through-art-with-the-na.

8 Platforma zprostředkovávajíci MOOC kurzy veřejnosti na adrese edX.org.

9 Art and Activity: Interactive Strategies for Engaging with Art. Dostupné z: https://www. coursera.org/learn/art-activity. 10 Platforma zprostředkovávající MOOC kurzy veřejnosti na adrese Coursera.org.

11 RITCHHART, Ron, CHURCH, Mark a Karin MORISON. Making Thinking Visible..., s. 55 . 


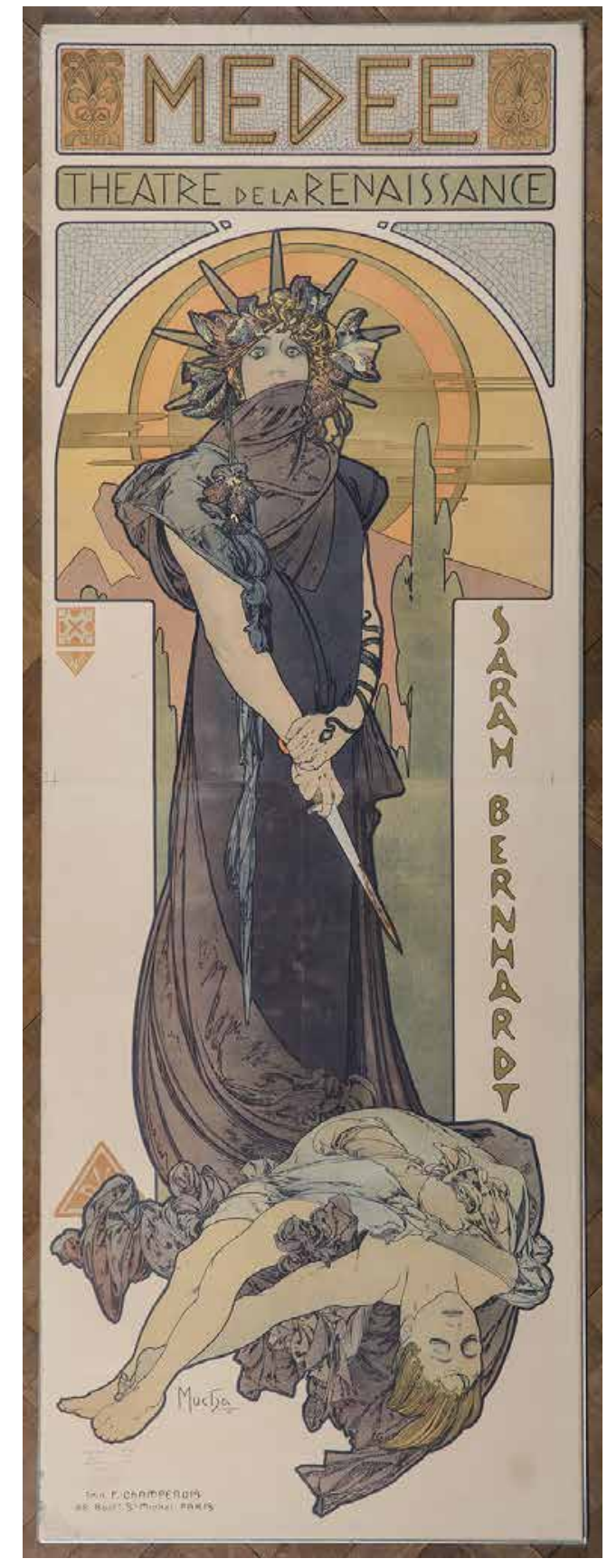

Médea, plakát Alfonse Muchy, který byl do sbírky Muzea v Ivančicích získán za finančního prispění $M K$ ČR. $V$ rámci kurzu byla jeho prostrednictvím prezentována metoda What makes you say that?

předchozí tvrzení potvrdí. ${ }^{12}$ Facilitátor se ptá po konkrétních prríčinách prohlášení účastníků - směřuje $\mathrm{k}$ podložení subjektivních výkladů objektivními důkazy. Tuto metodu lze zapojit i do běžné konverzace a jejím prostřednictvím se snažíme lépe porozumět způsobu uvažování, který vedl k určitému vyjádření. Elaboration Game je metoda, v níž jednotliví participanti hledají nové a nové detaily na obraze či jiném předmětu a přitom navazují na detaily, kterých si všimli ostatní ${ }^{13}$. Poslední představenou rutinou byly Creative Questions. Jádrem aktivity je snaha vybudit účastníky k položení otázek, které začínají vybranými slovy či frázemi (např. Co by se změnilo, kdyby...) v souvislosti s vybraným předmětem ${ }^{14}$. Organizace cvičení může být různá: Účastníci je mohou psát, jednu z nich vybrat a tu položit. Mohou je napsat a vhodit do nádoby, ze které je průvodce vylosuje. Nebo můžeme vybrat jen jedno počáteční slovo (či frázi), dát návštěvníkům čas na zamyšlení a po chvíli možnost otázku položit. Tato metoda může být využita v běžné komentované prohlídce jako alternativa k obligátnímu: „Máte nějaké otázky?"

Metody vybrané pro první konání minikurzu (kromě splnění jmenovaných požadavků stanovených na začátku př́pravy projektu) rozvíjely různé druhy myšlení a je možné je zařadit $\mathrm{v}$ různých fázích komentované prohlídky či edukačního programu. Během dalších setkání byly prezentovány vždy nové metody, např. Looking 10x2, Zoom In či Observational Drawing.

Další fázi př́ípravy představoval výběr sbírkových předmětů, jež budou sloužit při demonstraci jednotlivých metod. Záměrně jsme se rozhodli nevyužívat exponáty, s nimiž pracovali účastníci ve výše popsaných MOOC kurzech, jež byly našimi inspiračními zdroji. Chtěli jsme prohloubit poznání a uvědomění si významu muzeálií ze sbírek Muzea Brněnska tak, aby bylo zjevné, že metody lze využívat na všech pobočkách. Nezbytnou součást vybraných metod představuje práce se samotným exponátem, která je postavena na jeho důkladném poznání. Proto jsme se snažili volit takové předměty, které byly v nedávné době nějakým zpơsobem prezentovány - díky tomu jsme mohli využít jejich aktuální (často profesionální) fotografie a strukturované informace získané 
od kurátorů, které již byly zformulovány, a nezatěžovali jsme tak odborné pracovníky více než bylo nutné. Dále jsme se rozhodli pracovat zejména s výtvarnými díly (ačkoliv se o ně nejednalo výhradně). $\mathrm{K}$ tomuto rozhodnutí vedla zvolená forma setkání (videohovory) - u výtvarných děl nedochází $\mathrm{k}$ tak velké informační ztrátě při prezentaci na obrazovce počítače. Nicméně $\mathrm{v}$ prípadných budoucích pokračováních kurzu bychom rádi více pracovali např́klad s listinami a mincemi.

Podstatné bylo také zvážení praktických aspektů organizace kurzu. Délku jednotlivých setkání jsme nastavili na 45-60 minut, účast na delším kurzu by byla pro průvodce komplikovaná, jelikož i v době uzavření muzeí plnili řadu povinností a také se jevila jako optimální vzhledem $\mathrm{k}$ tomu, že výuka byla realizovaná formou videohovoru a po 60 minutách se začíná výrazně projevovat únava participantů. Průvodci byli v průběhu kurzu postavení do role návštěvníků: Jednotlivé metody si tak aktivně sami zkoušeli. Zúžený teoretický základ byl zařazen na konec programu tak, aby mohli průvodci př́padně pokračovat $\mathrm{v}$ samostatném studiu, ale nebyli hned na začátku setkání zahlceni př́iliš abstraktními a pro praxi méně stěžejními informacemi. K dalšímu studiu jsme doporučovali jak zdrojové publikace, tak MOOC kurzy, jež sloužily jako inspirační zdroje. Součástí každého setkání byla také závěrečná diskuze nad praktickým využitím daných metod na konkrétních pobočkách. Byly pojmenovávány překážky užití metod, ale i pozitiva a konkrétní možnosti jejich implementace do běžného provozu instituce.

Zásadní aspekt představovala také dobrovolnost kurzů. V průběhu jednotlivých setkání byli účastníci vedeni ke sdílení vlastních nápadů, myšlenek a otázek - úspěch tohoto procesu je podpořen, pokud se participanti zapojují dobrovolně a na základě vnitřní motivace. Abychom omezili př́padné bariéry, bylo možné se kurzů účastnit v pracovní době. Tato strategie se ukázala jako úspěšná, každého kurzu se účastnilo od 5 do 10 zájemců, což byl vzhledem k charakteru setkání optimální počet.

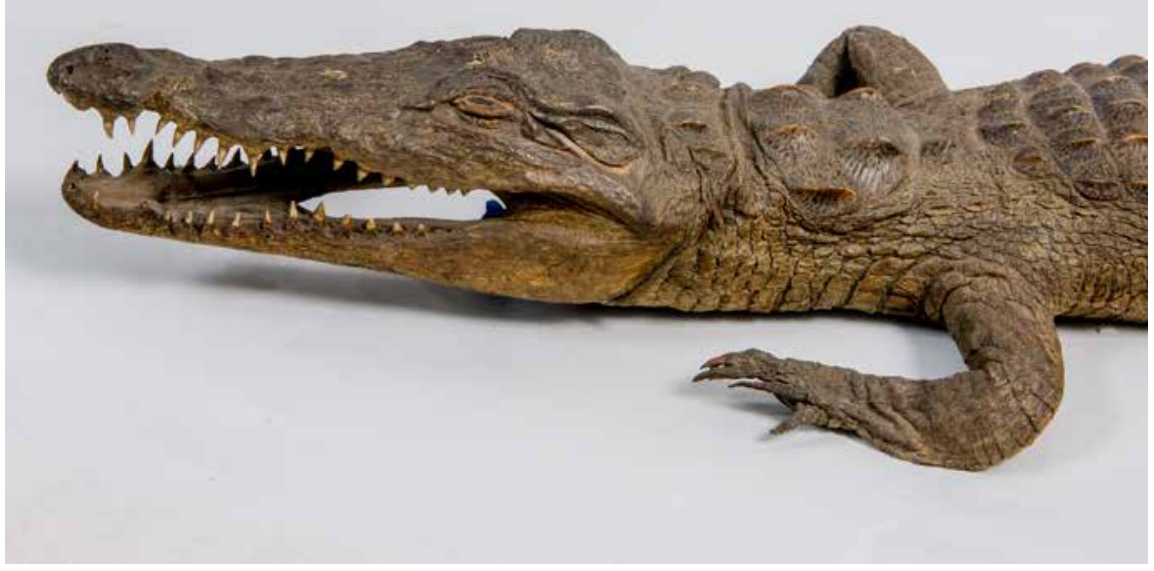

Krokodýl nilský, preparát mláděte ze sbíreky Muzea ve Šlapanicích, který byl využit pro prezentaci metody Creative Questions

\section{Závěrem: zpětná vazba, úspěšnost, možnosti dalšího rozvoje}

Hlavním cílem bylo vybavit zaměstnance, často vysoce kvalifikované profesionály s dlouhou praxí, sadou nástrojů, které následně mohou využít, autonomně a na základě vlastní motivace, $\mathrm{k}$ vylepšení své praxe. $\mathrm{V}$ průběhu roku byla realizována 4 setkání, $\mathrm{v}$ jednom př́padě s opakovaným programem (někteří kolegové, kteří měli o kurz zájem, se původního termínu nemohli zúčastnit). Celkem bylo v rámci kurzů prezentováno 9 různých metod, kurzů se účastnilo 15 kolegů, řada z nich opakovaně, zastoupeny byly všechny pobočky muzea. Kromě průvodců o kurzy projevili z vlastní iniciativy zájem také dva kurátoři. $V$ závěru roku byl účastníkům distribuován dotazník, $\mathrm{v}$ němž většina $\mathrm{z}$ nich uvedla, že $\mathrm{k}$ účasti je vedl zájem o poznání nových metod pro vlastní práci a prezentované metody považují za využitelné v praxi. Dále by se naprostá většina respondentů podobného kurzu zúčastnila i v budoucnu a kurz by také doporučila kolegům.

Aktuálně plánujeme další rozvoj těchto kurzů v roce 2021 a uvažujeme i o dalších formách vzdělávání, které by již mohly probíhat prezenční formou. Rádi bychom se tentokrát věnovali cíleněji kolegům, kteří pracují se školními skupinami a rodinami s dětmi. Zaměříme se $s$ největší pravděpodobností na metody z oblasti didaktiky dramatické výchovy a vybírat budeme zejména ty, které pracují přímo 


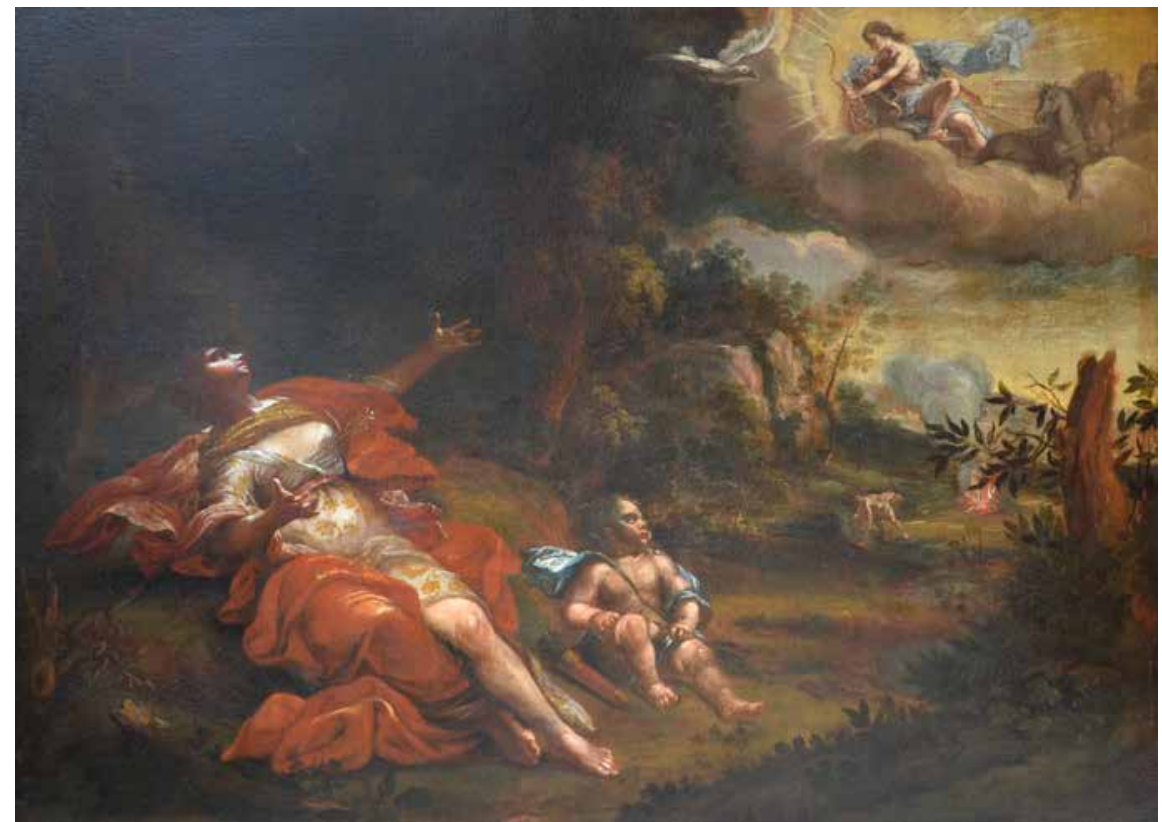

Obraz, který byl využit během kurzů $k$ prezentaci metody See/Think/Wonder. Apollón a Korónis, neznámý autor, 1. polovina 18. století, olej na plátně, ze sbírky Podhoráckého muzea
15 Zejména: MACHKOVÁ, Eva. Metodika dramatické výchovy: zásobník dramatických her a improvizací. 13. vydání. Praha: Národní informační a poradenské středisko pro kulturu, 2015. ISBN 978-80-7068-298-2.

16 WAY, Brian. Rozvoj osobnosti dramatickou hrou. 2. rev. a aktualiz. vyd. Praha: Sdružení pro tvořivou dramatiku, 232 s., 2014. ISBN 978-80-903901-4-0. 17 Napríklad: JACKSON Anthony. Inter-acting with the Past - the use of participatory theatre at museums and heritage sites. In: Research in Drama Education: The Journal of Applied Theatre and Performance, 5:2, 199-215, 2000. DOI: $10.1080 / 713692887$. s muzeáliemi, případně jejich kopiemi, a dále ty metody, které směřují $\mathrm{k}$ rozvoji soustředění a percepce. Vycházíme přitom zejména z publikací Evy Machkové ${ }^{15}$, Briana Waye ${ }^{16}$ a výzkumů Anthonyho Jacksona ${ }^{17}$. Nicméně uvažujeme také nad další podporou kolegů, kteří se věnují převážně dospělým návštěvnickým skupinám, zejména bychom se chtěli zaměřit na možnosti sdílení zkušeností a obtíží, jež budou vycházet z praxe.

Další vzdělávání pracovníků v muzeích patří k tématům, kterým je právem věnována pozornost, at' už se jedná o vzdělávání mimo muzeum nebo napříč institucí. Vytváření platforem uvnitř muzejních organizací, které vedou ke vzájemnému učení mezi zaměstnanci, a tím $\mathrm{k}$ dalšímu rozvoji individuálních dovedností i zvyšování úrovně muzejní práce, považujeme za praktický a ekonomicky výhodný způsob dalšího vzdělávání, který podporuje rozvoj dobrých vztahů a atmosféru vzájemné úcty mezi zaměstnanci. Projekt ,,minikurzů" pro průvodce se věnoval právě vytvoření takové platformy $\mathrm{v}$ jedinečné situaci, která do určité míry představovala komplikaci pro muzejní práci, na druhou stranu ale také poskytla prŕležitost zamyslet se nad dosavadní praxí a využit čas k jejímu zkvalitnění a inovování.

\section{Použité zdroje}

Art and Activity: Interactive Strategies for Engaging with Art [online]. Dostupné z: https://www.coursera.org/learn/ art-activity.

JACKSON, Anthony. Inter-acting with the Past - the use of participatory theatre at museums and heritage sites. In: Research in Drama Education: The Journal of Applied Theatre and Performance, roč. 5, č. 2 (2000), s. 199-215, DOI: 10.1080/713692887.

MACHKOVÁ, Eva. Metodika dramatické výchovy: zásobník dramatických her a improvizací. 13. vydání. Praha: Národní informační a poradenské středisko pro kulturu, 2015. ISBN 978-80-7068-298-2.

Project Zero: Visible Thinking [online]. Dostupné z: http://www.pz.harvard. edu/projects/visible-thinking.

RITCHHART, Ron, CHURCH, Mark a Karin MORISON. Making Thinking Visible: How to Promote Engagement, Understanding, and Independence for All Learners. San Francisco: Jossey-Bass, 2011.

Teaching Critical Thinking through Art [online]. Dostupné z: https://www.edx. org/course/teaching-critical-thinking-through-art-with-the-na.

TISHMAN, Shari a Patricia PALMER. Artful Thinking: Stronger Thinking and leasing through the power of art. Final report submitted to Traverse Area of Public Schools [online]. November, 2006. Dostupné z: http://www.pz.harvard.edu/resources/ final-report-artful-thinking.

TISHMAN, Shari a Patricia PALMER. Works Of Art Are Good Things To Think About. In: Evaluating the Impact of Arts and Cultural Education, conference proceedings. Paris: Centre Pompidou, 2007.

WAY, Brian. Rozvoj osobnosti dramatickou hrou. 2. rev. a aktualiz. vyd. Praha: Sdružení pro tvořivou dramatiku, 232 s., 2014. ISBN 978-80-903901-4-0. 